\title{
Measuring blood pressure in the elderly: Does atrial fibrillation increase observer variability?
}

\author{
D Sykes, R Dewar, K Mohanaruban, K Donovan, F Nicklason, D M Thomas, D Fisher
}

\begin{abstract}
Objective-To compare the interobserver and intraobserver variability of blood pressure measurements in geriatric patients in atrial fibrillation and in sinus rhythm.

Design-Prospective assessment of blood pressure measurements carried out in random order in two groups of elderly patients by five doctors unaware of the aims of the study.

Setting-Acute assessment wards for geriatric medicine, Cardiff Royal Infirmary.

Patients - 50 Elderly patients in sinus rhythm and 50 in atrial fibrillation.

Main outcome measures - Interobserver and intraobserver variability of blood pressure measurements in the two groups expressed as the coefficient of variability and compared by the Mann-Whitney $U$ test.

Results-Interobserver variability was significantly greater in the patients with atrial fibrillation for both systolic and diastolic pressures. Intraobserver variability was significantly greater in the atrial fibrillation group for diastolic pressures but the difference was not significant for systolic pressures. These differences were not related to pulse rate, age, or level of blood pressure.

Conclusions-The findings suggest that in the presence of atrial fibrillation physicians' interpretations of Korotkoff sounds are less uniform, which may have important clinical implications. Possibly a standardised methodology may overcome this problem.
\end{abstract}

\section{Introduction}

The vascular complications of hypertension are well recognised, as are the benefits of treatment, in both young and elderly subjects.' ${ }^{2}$ In clinical practice, however, management decisions are often difficult particularly in the elderly, who are more prone to adverse effects. ${ }^{3}$ Atrial fibrillation is commonly associated with hypertension, especially in the elderly, ${ }^{+}$and the irregularity of the pulse tends to make blood pressure measurement more difficult. This study was designed to see whether this subjective difficulty results in greater observer variability when measuring blood pressure in patients with atrial fibrillation and to identify the source of any increased variability.

\section{Subjects and methods}

The magnitude of observer variability reported in previous studies' was used to estimate the number of patients required to give a greater than $85 \%$ power in detecting a $5 \mathrm{~mm} \mathrm{Hg}$ difference in variability (at the $5 \%$ level of significance) between atrial fibrillation and sinus rhythm. Fifty patients with electrocardiographically confirmed atrial fibrillation and 50 in sinus rhythm were studied. All were inpatients in the acute assessment geriatric ward. In all cases the blood pressure was recorded at rest by five physicians using a Hawksley random zero sphygmomanometer and the method recommended by the British Hypertension
Society. ${ }^{6}$ One doctor also recorded the blood pressure twice further. The doctors making the measurements (DS, RD, KM, KD, FN) were recruited by the study organiser (DF) and kept blind to the aims of the study to avoid biasing the results. The order in which the doctors made the recordings was randomly allocated. Measurements on each patient were all made within a 15 minute period and pulse rate, age, and medicines being given were also recorded. For each patient interobserver variability (five recordings) and intraobserver variability (three recordings) were expressed as the coefficient of variability. The variability of the atrial fibrillation and sinus rhythm groups was then compared by the Mann-Whitney U test. The median difference (with $95 \%$ confidence intervals) between the variability in sinus rhythm and atrial fibrillation was also calculated. The relation between the individual variability and the blood pressure level, age, and pulse rate were examined by linear regression.

\section{Results}

Table I gives the patient characteristics. The two groups of patients did not differ with regard to age and male to female ratio. The pulse rate and mean systolic

TABLE I-Characteristics of patients

\begin{tabular}{|c|c|c|c|}
\hline & & $\begin{array}{l}\text { Patients in } \\
\text { sinus rhythm } \\
(\mathrm{n}=50)\end{array}$ & $\begin{array}{l}\text { Patients in } \\
\text { atrial } \\
\text { fibrillation } \\
(\mathrm{n}=50)\end{array}$ \\
\hline Age (years) & $\begin{array}{l}\text { Range } \\
\text { Mean }(\mathrm{SD})\end{array}$ & $\begin{array}{c}63-96 \\
80 \cdot 0(6 \cdot 9)\end{array}$ & $\begin{array}{c}71-92 \\
80 \cdot 8(5 \cdot 6)\end{array}$ \\
\hline $\begin{array}{l}\text { Pulse rate } \\
\text { (beat } / \mathrm{min})\end{array}$ & $\begin{array}{l}\text { Range } \\
\text { Mean }(\mathrm{SD})\end{array}$ & $\begin{array}{c}64-112 \\
84 \cdot 9(9 \cdot 0)\end{array}$ & $\begin{array}{l}60-104 \\
78(9 \cdot 9)\end{array}$ \\
\hline $\begin{array}{l}\text { Systolic blood pressure } \\
(\mathrm{mm} \mathrm{Hg})\end{array}$ & $\begin{array}{l}\text { Range } \\
\text { Mean }(\mathrm{SD})\end{array}$ & $\begin{array}{c}86-204 \\
150 \cdot 2(25 \cdot 1)\end{array}$ & $\begin{array}{c}91-209 \\
137 \cdot 8(29 \cdot 2)\end{array}$ \\
\hline $\begin{array}{l}\text { Diastolic blood pressure } \\
\text { (mm Hg) }\end{array}$ & $\begin{array}{l}\text { Range } \\
\text { Mean }(\mathrm{SD})\end{array}$ & $\begin{array}{c}41-115 \\
77 \cdot 6(13 \cdot 9)\end{array}$ & $\begin{array}{c}47-106 \\
71 \cdot 1(14 \cdot 8)\end{array}$ \\
\hline $\begin{array}{l}\text { No of men/No of women } \\
\text { No taking digoxin }\end{array}$ & & $\begin{array}{c}14 / 36 \\
2\end{array}$ & $\begin{array}{c}18 / 32 \\
33\end{array}$ \\
\hline
\end{tabular}

and diastolic blood pressures, however, were substantially lower in the atrial fibrillation group. Apart from many more patients taking digoxin in the atrial fibrillation group the number and types of drugs being used in the two groups were similar. There was a highly significantly greater interobserver variability in the group with atrial fibrillation for both systolic and diastolic pressures. By contrast, there was no significant difference in intraobserver variability between the two groups for systolic pressure, though a small but statistically significant difference was noted for diastolic pressure (table II). There was no clear relation between the degree of variability in an individual patient and his or her age, pulse rate, or level of blood pressure (table III).

\section{Discussion}

Many studies have noted observer variability in blood pressure measurement of a similar magnitude to our findings. ${ }^{54}$ The sources of error identified include faulty or improperly used equipment, expectation 
TABLE II - Variability in blood pressure measurements expressed as coefficient of variability

\begin{tabular}{|c|c|c|c|c|}
\hline & & $\begin{array}{l}\text { Patients in } \\
\text { sinus rhythm } \\
(\mathrm{n}=50)\end{array}$ & $\begin{array}{l}\text { Patients in } \\
\text { atrial fibrillation } \\
(\mathrm{n}=50)\end{array}$ & $\begin{array}{l}\text { p Value } \\
\text { (Mann- } \\
\text { Whitney } \\
\text { U test) }\end{array}$ \\
\hline \multicolumn{5}{|c|}{ Interobserver variability } \\
\hline $\begin{array}{l}\text { Systolic blood pressure } \\
(\mathrm{mm} \mathrm{Hg})\end{array}$ & $\begin{array}{l}\text { Range } \\
\text { Median } \\
\text { Median difference between } \\
\quad \text { groups }(95 \% \text { confidence interval })\end{array}$ & 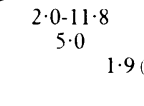 & $\begin{array}{c}1 \cdot 5-28 \cdot 0 \\
7 \cdot 0 \\
0 \cdot 3 \text { to } 3 \cdot 2)\end{array}$ & 0.0013 \\
\hline $\begin{array}{l}\text { Diastolic blood pressure } \\
\quad(\mathrm{mm} \mathrm{Hg})\end{array}$ & $\begin{array}{l}\text { Range } \\
\text { Median } \\
\text { Median difference between } \\
\quad \text { groups ( } 95 \% \text { confidence interval) }\end{array}$ & $\begin{array}{l}1 \cdot 6-33 \cdot 6 \\
5 \cdot 90 \\
3 \cdot 3\end{array}$ & $\begin{array}{c}3 \cdot 4-27 \cdot 4 \\
9 \cdot 65 \\
1 \cdot 5 \text { to } 4 \cdot 9)\end{array}$ & $0 \cdot 0009$ \\
\hline \multicolumn{5}{|c|}{ Intraobserver variability } \\
\hline $\begin{array}{l}\text { Systolic blood pressure } \\
\quad(\mathrm{mm} \mathrm{Hg})\end{array}$ & $\begin{array}{l}\text { Range } \\
\text { Median } \\
\text { Median difference between } \\
\quad \text { groups ( } 95 \% \text { confidence interval) }\end{array}$ & $\begin{array}{l}0 \cdot 7 \cdot 14 \cdot 3 \\
3 \cdot 8 \text {. } \\
\quad 1 \cdot 0\end{array}$ & $\begin{array}{r}0 \cdot 4-18 \cdot 2 \\
5 \cdot 3 \\
-0 \cdot 3 \text { to } 2 \cdot 2)\end{array}$ & $0 \cdot 140$ \\
\hline $\begin{array}{l}\text { Diastolic blood pressure } \\
(\mathrm{mm} \mathrm{Hg})\end{array}$ & $\begin{array}{l}\text { Range } \\
\text { Median } \\
\text { Median difference between } \\
\quad \text { groups ( } 95 \% \text { confidence interval) }\end{array}$ & $\begin{array}{l}0 \cdot 8-18 \cdot 0 \\
\quad 4 \cdot 15 \\
\quad 1 \cdot 7\end{array}$ & $\begin{array}{c}1 \cdot 0-26 \cdot 3 \\
6 \cdot 15 \\
0 \cdot 3 \text { to } 3 \cdot 2)\end{array}$ & $0 \cdot 012$ \\
\hline
\end{tabular}
variability with other factors

\begin{tabular}{|c|c|c|c|c|}
\hline & $\begin{array}{c}\text { SD systolic } \\
\text { blood } \\
\text { pressure }\end{array}$ & $\begin{array}{l}\text { Systolic } \\
\text { blood } \\
\text { pressure }\end{array}$ & Age & Pulse rate \\
\hline \multicolumn{5}{|c|}{ Sinus rhythm } \\
\hline SD systolic blood pressure & - & $0 \cdot 28$ & $0 \cdot 004$ & $-0 \cdot 100$ \\
\hline Systolic blood pressure & - & - & 0.057 & -0.098 \\
\hline Age & - & - & & -0.007 \\
\hline \multicolumn{5}{|c|}{$\mathrm{p}>0.05$} \\
\hline \multicolumn{5}{|c|}{ Atrial fibrillation } \\
\hline SD systolic blood pressure & - & $0 \cdot 195$ & -0.066 & $-0 \cdot 151$ \\
\hline Systolic blood pressure & - & - & $0 \cdot 125$ & 0.066 \\
\hline Age & - & - & - & -0.045 \\
\hline
\end{tabular}

bias, digit preference, and auditory acuity. ${ }^{5111}$ No study has sought to exclude these sources of error and look specifically at the influence of cardiac rhythm on observer variation. The important finding of our study is that atrial fibrillation is associated with a greater interobserver variability in the measurement of blood pressure but does not seem to affect intraobserver variability to the same extent. This suggests that the source of the increased variability is individual doctors' different interpretation of Korotkoff sounds. In atrial fibrillation there is baseline variation in blood pressure and the onset and disappearance of the sounds are more difficult to identify with a specific pressure reading.

There are at present no recommendations for measuring blood pressure in atrial fibrillation, so that some doctors may record systolic pressure at the first appearance of sounds whereas others may wait until these are consistently present. A similar problem may arise with the disappearance of sounds and the recording of diastolic pressure. Guidelines should make it possible to overcome this increased observer variation by using the first appearance and final disappearance of the sounds to record systolic and diastolic pressures. This, however, may result in the overestimation of the effective systolic pressure and an artificially lowered reading for the diastolic pressure. The order of magnitude of the variability found is $10 \%$, which would certainly be enough to affect clinical management decisions. The difficulties in setting guidelines for a single estimate of blood pressure suggest that a more prudent course would be to use repeated recordings. This reinforces the importance of not making decisions on the basis of a single recording, particularly in the presence of atrial fibrillation.

We thank Dr T J Peters for statistical advice and Mrs A Douglas for secretarial work.

1 Amery A, Birkenhager W, Bulpitt C, et al. Mortality and morhidity results from the European Working Party on High Blood Pressure in the Elderls trial EWPHE Lance 1985;:1349-5

2 Veterans Administration Cooperative Studv Group on Antihipertensive Agents. Effects of treatment on morbidity in hypertension. F.A.MA 1970; Agents. Effeets

3 Jackson G, Mahon W, Pierscianowsky TA, et al. Inappropriate antihspertensive therapy in the elderlv. Lancet 1976;ii: 1317 .

+ Wolf PA, Dawher TR, Thomas HE, et al. Epidemiologic assessment of chronic atrial fibrillation and risk of stroke: the Framingham study. Neurology 1978:28:973-7.

5 Bruce NG, Shaper AG, Walker M, et al. Observer bias in blood pressure studies. F Hypertens 1988;6:375-80

6 Petrie JC, O'Brien ET, Littler WA, et al. Recommendations on blood pressure measurement by a working party of the British Hypertension Society. Br.Med J 1986;293:611-5

7 Campbell MJ, Gardner MJ. Calculating confidence intervals for some nonparametric analyses. In: Gardner MJ, Altman DG, eds. Confidence intervals and statistical guidelines. London: British Medical Journal, 1989:74-9.

8 Hla KM, Vokaty KA, Feussner JR. Observer error in systolic blood pressure me.

9 Nielsen PE, Oxenboll B, Astrad K, et al. Auscultatory measurement of blood pressure performed by the doctor on duty. Acta Med Scand 1975;198:35-7.

10 Patterson HR. Sources of error in recording the blood pressure of patients with hypertension in general practice. Br.Med f 1984;289:1661-4.

11 O'Brien E, Fitzgerald D, O'Malley K. Blood pressure measurement: current practice and future trends. Br. Med $\mathcal{F}$ 1985:290:729-34.

Accepted 28 November 1989
Departments of

Gastroenterology and

Chemical Pathology,

Charing Cross Hospital,

London W6 8RF

Richard H T Loke, MRCP, research fellow

Iain M Murray-Lyon, FRCP, consultant physician and

gastroenterologist

Graham D Carter, MSC,

principal biochemist

Correspondence to: $\operatorname{Dr} \mathrm{R} \mathrm{H}$

T Loke, Department of

Gastroenterology,

University College Hospital,

London WC1.

BrMed f 1990;300:163-4

\section{Postural hypotension related to zidovudine in a patient infected with HIV}

\author{
Richard H T Loke, Iain M Murray-Lyon, \\ Graham D Carter
}

Disease of the adrenal glands is common in patients with AIDS. ${ }^{12}$ Clinical adrenocortical insufficiency, though less common, is increasingly recognised. ${ }^{3}$ We report a case in which adrenocortical insufficiency was brought to our attention by symptoms repeatedly precipitated by zidovudine.

\section{Case report}

A 49 year old homosexual first presented in October 1987 with an eczematous rash and mild oral candidiasis. His rash cleared after a short course of $0.025 \%$ betamethasone ointment. He had serological evidence of past hepatitis B infection and of antibodies to HIV. In April 1988 he received a two week course (his first) of ketoconazole for oral candidiasis.

Because of tiredness, weight loss (body weight $53 \mathrm{~kg})$, and a reduced CD4-lymphocyte count $(0.055$ $\times 10^{4} / \mathrm{l}$ ) he was started on zidovudine $200 \mathrm{mg}$ every four hours in June. Within an hour after his first oral dose he experienced hunger and dizziness for about 30 minutes, and these recurred after every subsequent dose. He was monitored before and after his dose, at 8 am, before breakfast. Twenty eight minutes after the dose he experienced his usual symptoms. Blood pressure (while he was seated) had decreased from a baseline of $115 / 65 \mathrm{mg} \mathrm{Hg}$ to $90 / 50 \mathrm{~mm} \mathrm{Hg}$ and was $90 /$ 60 and $86 / 60 \mathrm{~mm} \mathrm{Hg} 15$ and 30 minutes thereafter, increasing to $110 / 74 \mathrm{~mm} \mathrm{Hg}$ two hours after the dose. He was pale, but his pulse remained regular and stable, ranging from 76 to 84 beats $/ \mathrm{min}$. Plasma sodium, potassium, calcium, albumin, and phosphate concentrations $0,30,60,90,120$, and 150 minutes after the dose were normal and did not change appreciably; the corresponding fasting blood glucose values were 3.9 , $3 \cdot 7,3 \cdot 5,3 \cdot 5,3 \cdot 7$, and $3 \cdot 6 \mathrm{mmol} / \mathrm{l}$. 